\title{
RESENHA: BRITO, TECA ALENCAR DE. UM JOGO CHAMADO MÚSICA: ESCUTA, EXPERIÊNCIA, CRIAÇÃO, EDUCAÇÃO. SÃO PAULO: PEIRÓPOLIS, 2019. 200 P.
}

Book review: BRITO, Teca Alencar de. Um jogo chamado música: escuta, experiência, criação, educação. São Paulo: Peirópolis, 2019. $200 p$.
Reseña: BRITO, Teca Alencar de. Um jogo chamado música: escuta, experiência, criação, educação. São Paulo: Peirópolis, 2019. $200 p$.

FLÁVIO RODRIGUES

Universidade Estadual de Campinas frodrigues89@hotmail.com

O livro Um jogo chamado música: escuta, experiência, criação, educação é o mais recente trabalho da educadora Teca Alencar de Brito, professora e pesquisadora aposentada do Departamento de Música da ECA-USP e fundadora da Teca Oficina de Música, núcleo de educação musical voltado à formação de crianças, jovens e adultos, criado em 1985 na cidade de São Paulo. Muitas das vivências nesses 34 anos de existência de sua oficina servem como relatos da proposta pedagógico-musical livre e criativa que propõe nesse trabalho: um jogo de "repetir diferente", reinventando continuamente a experiência e propondo uma participação ativa de todos os envolvidos. "Um jogo chamado música" é também o título de uma oficina ministrada pela autora ao longo de muitos anos e diferentes contextos.

Pautando-se na ideia de jogo ideal - aquele que se joga pelo prazer de jogar e que desconhece ganhadores ou perdedores - proposto pelo filósofo francês Gilles Deleuze (1925-1995), Teca defende a abordagem desse conceito no contexto musical colocando-o como um fazer em si mesmo, sem usá-lo como uma "simplificação" de conteúdos mecanicistas ou como "receitas" a serem seguidas para memorização de saberes.

Rechaçando também a ideia de método ou cartilha, o livro, recheado de experiências aplicadas pela perspectiva do jogo, se coloca em consonância com o pensamento de outros importantes educadores da segunda metade do século XX, como o canadense Murray Schafer, que, no prefácio de seu livro O ouvido pensante, escreve: "Nenhuma coisa, neste livro, diz: Faça deste modo. Ele apenas diz: Eu fiz assim" (Schafer, 1991, p. 14). 
Os relatos revelam um imenso poder de recriação e aplicações práticas para diferentes contextos. Esta é, portanto, uma das potências desse trabalho: ao não se afirmar como método e sim como descrição, torna cada uma das experiências propostas em possibilidades, levando em consideração as particularidades de cada grupo e entendendo a música enquanto fazer social e comunitário, não se fechando num mero meio de adquirir capacidades técnicas. Evidencia, dessa maneira, o poder das atividades como ferramentas que disparam sensações, promovem a escuta, o criar, pensar, mover-se, etc.

O livro se divide em três momentos distintos, precedido de uma apresentação da presidente do Instituto Arte na Escola, Evelyn Berg Ioschpe, e outra da própria autora. Ao final da terceira parte, encontramos um glossário, uma galeria de fotos e referências. Um prefácio, assinado pela também educadora musical Marisa Trech Fonterrada, ressalta como o trabalho de Teca nesse livro se afasta de propostas pedagógicas que visam facilitar conceitos ou entender o jogo como mera diversão, colocando-o como um fazer criativo e dinâmico. Além disso, ressalta a importância dos alunos, crianças e jovens de idades variadas, que participaram ativamente da construção desses relatos.

No primeiro capítulo, intitulado "Sobre o fazer musical", Teca procura, agora de maneira mais detalhada, traçar as bases teóricas que permeiam suas ações como educadora. Definindo o fazer musical como "o contato entre a realização acústica de um enunciado musical e seu receptor, seja este alguém que cante, componha, dance ou simplesmente ouça" (p. 35, citando Ferraz, 1994, p. 18), ela desenvolve seu pensamento a partir de duas concepções: de que os seres humanos são, dentre outras características que nos constituem, seres musicais; e de que a cultura se iniciou com o jogo.

O entendimento do ser humano como ser musical e o foco na interação, difundido por diversos autores, ganhou nos trabalhos de Christopher Small (1927-2011), pesquisador da área da sociologia que dedicou grande parte de suas obras à arte e cultura, a denominação de musicking (musicar). "Desde jovem eu acreditava que o dom da música é tão universal como o dom da fala, e que todo ser humano nasceu com esse dom" (Small, 1999, p. 1, tradução minha). ${ }^{1}$ Dessa forma, desloca o olhar dos registros, partituras e instrumentos e o coloca na relação social e nas ações e interações geradas nesse contato. Apesar de não haver citação direta do autor ou termo, Teca parece influenciada por essas ideias em seu trabalho, situando suas práticas a contínuos processos de reorganização do ser humano, ressaltando a importância simbólica que a escuta passou a ter ao longo dos anos.

Sobre o jogo, o trabalho do historiador Johan Huizinga (1872-1945), que cunhou o termo Homo ludens, alusão ao caráter lúdico do jogar e sua importância na formação cultural do ser humano (Huizinga, 2000), parece ter papel central, assim como o já citado Deleuze e seu "jogo ideal". François Delalande (1941-), que relacionou o fluxo de condutas musicais no curso da

\footnotetext{
1 “Desde joven he creido que el don de la música es tan universal como el don del habla, y que todo ser humano nació con ese don."
} 
infância a conceitos do psicólogo suíço Jean Piaget (1896-1980), também tem sua ideia amplamente explorada pela autora ao lado do filósofo e psicólogo brasileiro Rubem Alves (1933-2014), que nos apresenta a analogia da "caixa de brinquedos", alegoria criada por Alves para se referir aos dois universos que coexistem dentro do homem: um, que seria a caixa de ferramentas, que guarda as coisas relacionadas à ordem da sobrevivência; e o outro, a caixa de brinquedos, responsável pela fruição, criatividade e imaginação. Para Teca, a música, na educação, deve interagir com as duas "caixas", criando alianças entre ambas.

Partindo, portanto, dessas concepções, defende uma abordagem ampla e diversa da música no contexto educacional, que escute e chame os alunos à participação e aponte para uma pedagogia aberta e humanizadora, voltada para o indivíduo e suas particularidades e, ao mesmo tempo, para o coletivo, citando Paulo Freire (1921-1997), Ilza Joly e Natália Severino.

No segundo capítulo, intitulado "Entrando no jogo musical", a autora dá uma especial atenção à escuta, situando a mesma como um ato de criação. Citando compositores como John Cage (1912-1992), Luc Ferrari (1929-2005) e o escritor Elias Canetti (1905-1994), que cunhou o termo Todo-Ouvidos, coloca o ouvir no primeiro plano das experiências de contato com o mundo exterior. Dessa forma, faz referências às escutas acusmáticas - o ato de ouvir sem contato visual com a fonte sonora.

No seguir do capítulo, Teca começa então a exposição de diversas vivências compartilhadas com diferentes grupos de alunos em seu espaço de educação. Essa exposição se dá, na maioria dos casos, com uma explicação do jogo proposto, ligando essa explicação à sua origem e contexto, e o relato detalhado dos procedimentos, que ela nomeia como desenvolvimento, seguido pelas respostas do grupo, demonstrando também objetivos alcançados ou desejados. Em alguns casos, a própria autora propõe variações de aplicação, sugere perguntas e até mesmo provocações.

São, ao todo, 19 relatos de experiências de jogos musicais, todos eles, é claro, em consonância com as ideias propostas no início do capítulo e no capítulo anterior, explorando escuta, criação, improvisação e, até mesmo, o uso de recursos tecnológicos, todos eles adaptáveis a diversas situações e grupos de diferentes tamanhos e idades.

No terceiro capítulo, batizado de "Outros saberes musicais", abre espaço para as propostas e vivências de diversos educadores, que relatam experiências de diferentes naturezas. Temos as participações de Adriana Rodrigues Didier, professora de música do Conservatório Brasileiro de Música do Rio de Janeiro, que propõe atividades com sons vocais; Berenice Almeida e Magda Pucci, educadoras que trazem propostas dentro do domínio da chamada "música indigena"; Fátima Carneiro dos Santos, professora do Departamento de Música e Teatro da Universidade Estadual de Londrina (UEL), com uma proposta de ampliação da ideia de música através da paisagem sonora; Fernando Barba e o Grupo Barbatuques, com uma proposta de exploração de sons corporais; Fernando Sardo, músico e educador, que traz uma vivência sobre a construção de instrumentos; Gabriel Levy, músico e educador, 
que desenvolve um trabalho no dominio das "músicas do mundo"; Janete El Haouli, musicista, que traz outra proposta envolvendo paisagem sonora; Lisbeth Soares, professora responsável pelo Programa de Apoio Pedagógico e Inclusão da Fundação das Artes de São Caetano do Sul, trazendo considerações sobre a educação musical inclusiva e, por fim, Stênio Biazon, educador musical, que relata uma experiência a partir de captadores do tipo piezo.

Todos as propostas dos colaboradores seguem, de maneira geral, a estrutura de: apresentação do contexto de seus trabalhos, o relato de uma vivência de sua proposta (alguns contendo excertos de partituras) e, por fim, referências. Em alguns casos, com o complemento de links para mais informações. Os currículos dos educadores musicais estão colocados como notas de rodapé na página inicial de cada um de seus relatos.

Seguindo, Teca escreve um breve texto de encerramento, batizado de "Fim do jogo", instigando o leitor a colocar as propostas e ideias em prática.

Por fim, é apresentado o glossário com os termos específicos usados na publicação, uma vasta galeria de fotos e as referências da autora.

Vale ressaltar também o material extra que complementa o trabalho. Ao entrar no site www.editorapeiropolis.com.br/umjogochamadomusica, ou acessar pelo $Q R$ code disponivel no livro, é possivel escutar diversas das experiências nele relatadas, além de conseguir visualizar as fotos presentes no material físico em tamanhos maiores. Dessa forma, a publicação se vale da tecnologia para potencializar seu poder enquanto relato de experiências e aproximar ainda mais o leitor das vivências propostas. Uma adição muito bem-vinda aos educadores musicais que anseiam por, além de imaginar as possibilidades que as práticas propostas podem atingir, ter referências auditivas que podem servir como sementes de ideias e possibilidades.

\section{REFERENCIAS}

HUIZINGA, Johan. Homo ludens. Tradução: João Paulo Monteiro. 4. ed. São Paulo: Perspectiva, 2000.

SCHAFER, Murray. O ouvido pensante. Tradução: Marisa Trench de O. Fonterrada, Magda R. Gomes da Silva, Maria Lúcia Pascoal. São Paulo: Fundação Editora da Unesp, 1991.

SMALL, Christopher. El musicar: un ritual en el espacio social. Trans: Revista Transcultural de Música, [s. l.], n. 4, 1999. Disponivel em http:// www.sibetrans.com/trans/articulo/252/elmusicarunritualenelespaciosocial. Acesso em: 28 nov. 2019. 
Flávio Rodrigues é músico, compositor e pesquisador. Mestrando em Etnomusicologia pelo Departamento de Música da Universidade Estadual de Campinas (Unicamp) com o projeto "Kawasuji Seiryu Daiko: música, tradição e identidade", é membro do grupo de pesquisa "Musicar Local - novas trilhas para a etnomusicologia" sob coordenação da Profa. Dra. Suzel Ana Reily. Graduado em Música (Licenciatura plena) pelo FIAM-FAAM Centro Universitário, com especialização em Musicoterapia Preventiva e Social pelas Faculdades Metropolitanas Unidas (FMU) e extensão em Gestão Cultural pela Pontifícia Universidade Católica de São Paulo (PUC-SP). Educador com 13 anos de experiência em escolas de música, escolas regulares e projetos sociais. Idealizador do Ruídos Podcast (www.ruidospodcast.com.br). https://orcid.org/0000-0003-4555-9011 